\title{
Climate Variation and Disturbance Regime Affect Stand Composition and Structure of the Boreal Forests in Southwest Yukon of Canada
}

\author{
Shyam K. Paudel1*, Suzanne W. Simard1, Craig R. Nitschke², John L. Innes ${ }^{1}$ \\ ${ }^{1}$ Faculty of Forestry, University of British Columbia, Vancouver, Canada \\ ${ }^{2}$ Department of Forest and Ecosystem Science, University of Melbourne, Parkville, Australia \\ Email: shyam.paudel@undp.org
}

Received 10 January 2015; accepted 19 March 2015; published 25 March 2015

Copyright (C) 2015 by authors and Scientific Research Publishing Inc.

This work is licensed under the Creative Commons Attribution International License (CC BY). http://creativecommons.org/licenses/by/4.0/

c) (i) Open Access

\begin{abstract}
The cold and dry boreal forests of the Southwest Yukon are dominated by white spruce (Picea glauca), trembling aspen (Populus tremuloides) and balsam poplar (Populus balsamifera), and the variability in structure and composition of stands depends on the favourability of disturbance, climate and site conditions for stimulating regeneration. In this study, we investigated relationships between stand structure and ecological, climatic and disturbance factors in the southwest Yukon. We found that white spruce dominates mature forests across the landscape, but it is regenerating proportionately less than trembling aspen. Nevertheless, regeneration of all the three species was abundant following any type or severity of disturbance. Height and diameter of both species varied with several environmental variables, particularly site physiography. Mixed stands of aspen and white spruce were more productive than pure stands of aspen or spruce. However, overall productivity in mixed stand decreased when density of aspen was more than 1000 stems/ ha. These results suggested that mixed stands of deciduous and coniferous species where appropriate should be promoted maintaining aspen density below 1000 stems/ha as the productivity declined beyond this threshold. Similarly, we suggest carrying out selection harvesting of co-dominant trees and regular thinning of intermediate trees to promote the height and diameter growth of the remaining trees.
\end{abstract}

\section{Keywords}

Stand Structure, Composition, Density, Basal Area, Climate Variability, Ecosystem, Disturbance

\footnotetext{
${ }^{*}$ Corresponding author.
}

How to cite this paper: Paudel, S. K., Simard, S. W., Nitschke, C. R., \& Innes, J. L. (2015). Climate Variation and Disturbance Regime Affect Stand Composition and Structure of the Boreal Forests in Southwest Yukon of Canada. Open Journal of Forestry, 5, 337-352. http://dx.doi.org/10.4236/ojf.2015.54029 


\section{Introduction}

Stand structure is an important attribute of forest ecosystems, with implications for forest health, biodiversity conservation and forest management (Kimmins, 1997; Kuuluvainen, 2002; Brassard and Chen, 2006) and is generally affected by multiple biogeoclimatic factors and the temporal and spatial scales of disturbances (Bonan and Shugart, 1989). Climate, disturbance and other biophysical factors determine structure and composition in the boreal forest (Bonan and Shugart, 1989; Larsen, 1980). Climatic and site factors influence the forest composition and future stand development by affecting post-fire recruitment in Alaska and Canada (Johnstone et al., 2004).

The magnitude and intensity of spatial and temporal disturbances shape landscape structural development by creating periodic gaps (Lorimer, 1989) and developing a mosaic of development patches of varying age and size structure (McCarthy and Weetman, 2006). As an increase in fire cycle is predicted to occur due to climate change (Bergeron and Flannigan, 1995; Flannigan et al., 1998), which would affect both stand structure and composition (Payette et al., 1989; Bergeron, 1991; Lloyd and Fastie, 2002), an understanding of disturbance and biogeoclimatic effects on stand structure will improve productivity predictions and inform management practices (Brassard and Chen, 2006).

The boreal forest is a complex mixture of uneven-aged stands (Martin and Gower, 2006). Its composition and structure change over time through successional processes (Bergeron and Dubuc, 1989; Bergeron, 2000). Climate change and its impact on disturbance regimes are becoming increasingly important issues in the boreal forest (Johnson et al., 2003). Climate in the Canadian north is changing significantly, with increases in temperature and precipitation reported over the last fifty years (Frugal and Prowse, 2008). As a consequence of this observed change in climate, an extensive spruce bark beetle (Dendroctonus rufipennis) (SBB) outbreak began in the early 1990s. The outbreak attained epidemic levels in the region after 1992 (Government of Yukon, 2004), with the infestation subsiding by 2007. Approximately 340,000 hectares of forest were affected by the beetle outbreak (Northern Climate Exchange 2006; Government of Yukon, 2010), which was the second largest infestation recorded after the infestation in south central Alaska, USA where the SBB killed approximately 1.2 million ha of white spruce stand (Berg et al., 2006). The outbreak is regarded as one of the most dramatic disturbance events to have affected the regions predominant mature white spruce (Picea glauca) forests (Berg et al., 2006).

The observed warming has also changed the characteristics of the region's fire regime (annual fire incidences, area burned and seasonal fire severity rating) beyond historic rates (McCoy and Burn, 2005). Between 1946 and 2003, 23 large fires and many small fires were recorded, burning approximately 100,100 ha of forest in the region (Government of Yukon, 2004). Under future climate change predictions for the region, the average annual frequency of fire and total area burned may double by the 2080s (McCoy and Burn, 2005). In response to the increase in forest disturbances in the region, the Yukon and Champagne-Aishihik governments developed a forest management plan to implement salvage harvesting to recover up to 1 million $\mathrm{m}^{3}$ of beetle-affected timber between 2006 and 2015 (Government of Yukon, 2004).

Studies in the boreal forest suggest that the frequency and severity of disturbances can affect vegetation dynamics, diversity patterns and ecosystem processes (Wardle et al., 1997). It is important that forest managers understand disturbance dynamics and their effects on ecosystem structure so that better management practices can be applied, yet such an understanding is still lacking for many forest types in the boreal forest (Martin and Gower, 2006). This understanding would help forest managers plan for maintaining required forest structural diversity, conserving biodiversity, applying specific habitat management practices, prioritizing areas for locally occurring species or applying practices that emulate natural disturbances.

The purpose of this study was to assess the variability in structure and composition of the boreal forests of the Southwest Yukon (SWY). We hypothesized that relationships among stand structure variables (diameter, density in stems per hectare, and basal area) vary significantly by stand type and are affected by edaphic factors. Specifically, we expected that mean stand diameter will decrease with increasing stand density, and this will be more pronounced in pure stand types and on sites with more fertile soils. We also expected higher stand productivity in pure stands compared to mixed stands. Similarly, we hypothesized that forest composition and forest productivity would vary significantly by disturbance type in the study area. Specifically, we expected that the density of white spruce would increase with any disturbance but that the proportion of broadleaved trees and regeneration 
would increase with disturbance severity, particularly following fire. We also hypothesized that stand structure and composition vary significantly with climatic variability. We expected greater stand productivity in warmer and wetter locations.

\section{Methodology}

\subsection{Study Area}

This study was carried out in the Champagne and Aishihik Traditional Territory (CATT) within SWY during years between 2008 and 2012. The CATT extends across four eco-regions of Yukon: the St. Elias Mountains, the Ruby Range, the Yukon Southern Lakes and the Yukon Stikine Plateau, representing a landscape of great diversity and variability. The study area covers an altitudinal range between $60.63^{\circ} \mathrm{N}$ and $61.2^{\circ} \mathrm{N}$ and longitudinal range between $-137.35^{\circ} \mathrm{W}$ and $-136.97^{\circ} \mathrm{W}$ (Figure 1). The elevation range of the study area is from 651 to $1158 \mathrm{~m}$ above Mean Sea Level (MSL). The climate of the study area is characterized by cold winters and warm and dry summers with mean annual temperature $-1.65^{\circ} \mathrm{C}$ andmean annual precipitation of $319.5 \mathrm{~mm}$. Soil texture varies from mixtures of sandy and silty fluvial deposits by rivers and lakes in lowland areas to mixtures of sandy and silty clays in the rest of the area. Permafrost is also common but discontinuous in the study area.

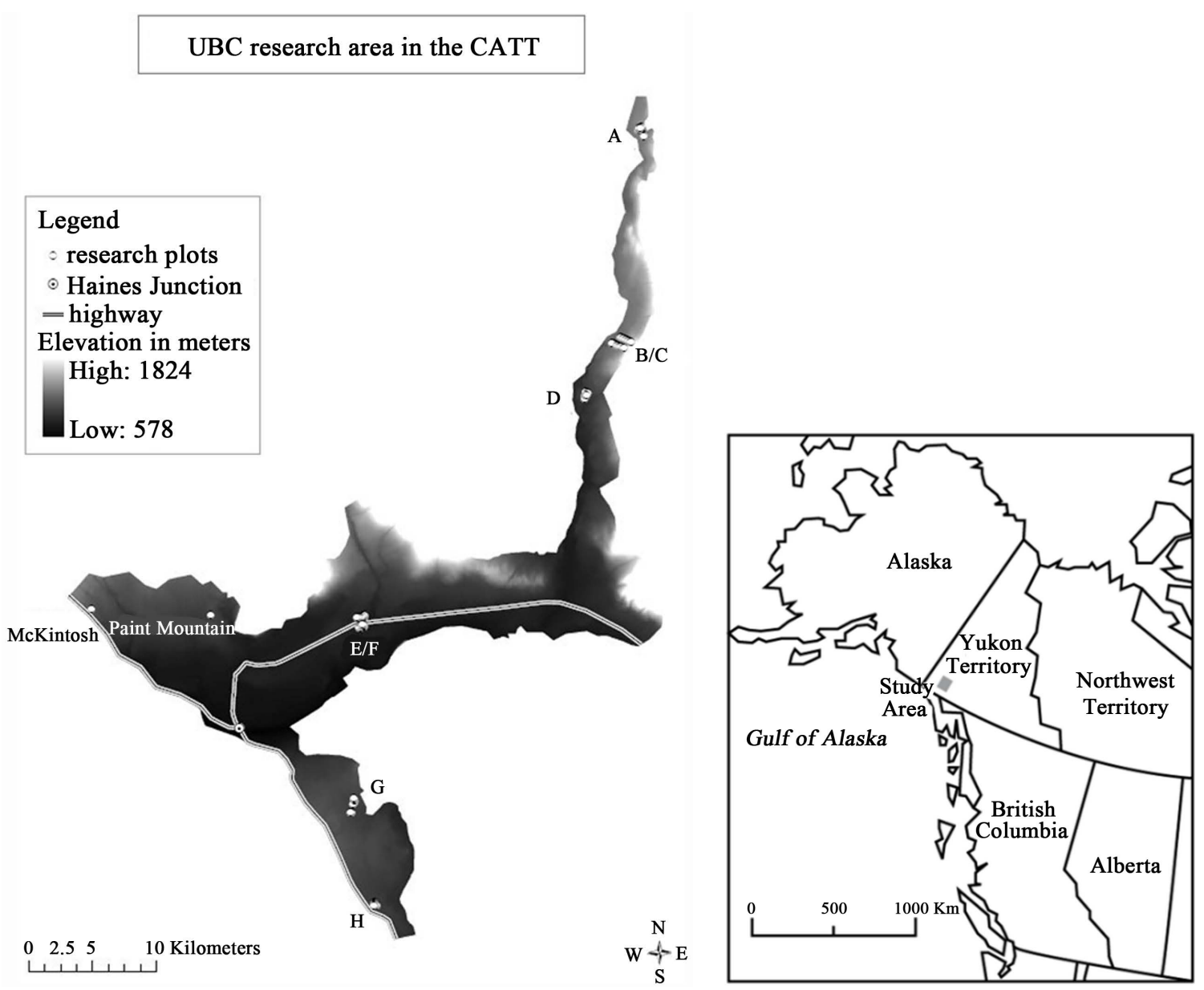

Figure 1. Map of the study area showing blocks and plots where the data were collected. [Note: A is mostly undisturbed forest predominantly consisting of white spruce with small patches of Populus tremuloides and Salix spp.; B and C have traces of old fire in 50\% of its plots and consists of predominantly Picea glauca with scattered patches of Salix spp.; D has old burnt logs in most of the plots and consists of Picea glauca and Populus tremuloides; E and F have been affected by spruce bark beetle and recent fire and has white spruce with scattered patches of Salix spp.; G has been disturbed by beetle and harvesting and consists mainly of Picea glauca trees; $\mathrm{H}$ is a harvested plot and has mixed forest of white spruce and aspen.] 
The study area is dominated by white spruce (Picea glauca, (Moench) Voss), followed by trembling aspen (Populus tremuloides Michx.) and balsam poplar (Populus balsamifera L.). The majority of the stands are between 80 and 120 years-old, although about 20\% of the stands are younger than 70 years-old (Government of Yukon, 2004). Sub-alpine and alpine plant communities are abundant in the mountainous areas above 1100 meters.

The majority of the study area has been disturbed by a spruce bark beetle (Dendroctonus rufipennis) infestation and by forest fires. Spruce bark beetles reached epidemic levels in the region after 1992, subsiding in 2007. Approximately 340,000 hectares of forest were affected by the beetle outbreak (NCE, 2006; Government of Yukon, 2010). Similarly, fire is common in the study area. Between 1946 and 2003, the region experienced 23 larger fires and numerous smaller fires (Government of Yukon, 2004). Most areas in the region were burned in 1950s.

\subsection{Data Collection}

Stratified systematic sampling (Kindt and Coe, 2005) was applied for the collection of data. Ecological, topographical and edaphic data were collected from 90 plots located along eight transects within the forested landscape of the CATT (Figure 1) in the summer of 2008.The plots were classified into five strata based on the disturbance type: a) undisturbed forest (control); b) an old fire-affected forest (more than 60 years-old with no trace of beetle); c) a recent fire-affected forest (less than 15 years-old and previously affected by beetle); d) a beetleaffected forest; and e) a salvage harvesting area (previously affected by beetle). The disturbed plots were identified and mapped using the local knowledge of the Yukon Government's Ministry of Energy, Mines and Resources (MEMR) and the Champagne and Aishihik First Nation (CAFN) government. The plots were also classified according to disturbance severity as follows: 1) high severity: disturbed by a combination of either spruce bark beetle and fire (fire plots) or spruce bark beetle and salvage harvesting (harvesting plots); 2) medium severity: disturbed more than $50 \%$ by spruce bark beetle infestation without fire and salvage harvesting (beetle plots); and 3) low severity plots: signs of old fire and not affected by spruce bark beetle (old fire plots; 1948 constitutes the earliest available data for this region, hence, older fires are grouped here).

For each transect, a point of commencement (POC) was chosen, which was generally a visible landmark nearby an access point. The first plot was selected $100 \mathrm{~m}$ from the POC along a random bearing. Subsequent plots were systematically located $100 \mathrm{~m}$ from the previous plot. At each plot location, a $20 \mathrm{~m} \times 20 \mathrm{~m}\left(400 \mathrm{~m}^{2}\right)$ plot was established to collect elevation, slope, aspect, latitude, longitude, tree density, and crown coverage data. Within each $400 \mathrm{~m}^{2}$ plot, three $25 \mathrm{~m}^{2}$ nested sub-plots were randomly selected to collect shrub and sapling data. Seedling density and herb, bryophyte, and lichen cover were collected separately from three additional randomly selected $1 \mathrm{~m} \times 1 \mathrm{~m}$ micro-plotslocated within the $25 \mathrm{~m}^{2}$ subplots. One soil pit was located in a randomly selected micro-plot for soil sampling and characterisation.

\subsection{Data Analysis}

Average height, diameter and basal area were calculated by species and dominance class. Density, total crown cover, and total basal area were calculated by disturbance type. Stand structure and composition was assessed using density index. Proportion (\%) of total density (number of stems/ha) comprised of trees, seedlings, and saplings was calculated by species. Species composition was assessed using basal area ratio of a species with the total basal area (Huang and Titus, 1995). The value ranges from 0 to 1 where value 0 indicates the absence of the species and 1 indicates a single species stand. We developed a density index to compare the density of trees, saplings and seedlings by species and disturbance regime with respect to average density on all 90 plots as follows;

$$
D_{i}=\left\{D_{d} \mid D_{t}\right\} * 100
$$

where $D_{i}$ is the density index, $D_{d}$ is the average density of tree, seedling or sapling in a particular disturbance regime and $D_{t}=$ average density of tree, sapling or seedling in 90 plots.

$\mathrm{R}^{2}$ values were calculated for the variables related to stand structure. Scatter plots with regression fit line were made when both dependent and independent variables are numerical and ANOVA was used for the nominal independent variables. The significant of the plots were tested for $95 \%$ confidence level $(P<.05)$. R software was used to calculate ANOVA, R squared values and to plot the relationship among variables (R Development core 
team, 2012). In addition to these statistical tools, Multiple Co-inertia Analysis (MCA) was used to assess the relationship between environmental variables and stand structure (Dray et al., 2003). ArcGIS 9.1 was used to illustrate the species distribution, crown cover and forest types in the study area (ESRI, 2009).

\section{Results}

\subsection{Stand Composition}

We sampled a total of 2944 trees in 90 plots. White spruce dominates the landscape with $87.5 \%$ stand coverage followed by aspen and balsam poplar, which cover $12.2 \%$ and $0.3 \%$, respectively (Table 1 ). Mixed stands had higher stand density (1063 stems/ha) than pure aspen stands (300 stems/ha) and white spruce stands (848 stems/ha). Similarly, white spruce had the highest sapling cover with $67.8 \%$, followed by aspen $(31.4 \%$ ) and balsam poplar (2.6\%) (Table 1). Stand density index analysis indicated that white spruce has the highest index (0.907) indicating the highest abundance on the landscape followed by aspen (0.09) and balsam poplar (0.001) (Table 2).

\subsubsection{Average Height, Diameter and Basal Area of Species by Height Class}

White spruce had the highest average height and diameter (Table 3). The average dominant height and diameter of white spruce were $16 \mathrm{~m}$ and $25.65 \mathrm{~cm}$, respectively. The average dominant heights of aspen and balsam poplar were $11.36 \mathrm{~m}$ and $7.35 \mathrm{~m}$ and the average dominant diameters were $18.95 \mathrm{~cm}$ and $15.1 \mathrm{~cm}$, respectively. Average diameter of white spruce was higher in older stands with low density. The average diameters significantly decreased when stand density exceeded 1000 stems per hectare (Figure 2).

In terms of height class, white spruce intermediate tree class had $24.3 \%$ of the total cover, the highest on the landscape, followed by white spruce co-dominant (20.6\%) and dominant trees (18.3\%). White spruce co-dominants had the highest basal area with $42.6 \%$ of the total in the landscape, followed by dominant $(23.2 \%)$ and intermediate (20.4\%) white spruce. Average height was higher in older stands (Figure 3). Similarly, trembling aspen had the highest number of co-dominant trees, covering $7.5 \%$ of total basal area, followed by its intermediate trees (6.7\%). Balsam poplar had $0.6 \%$ of dominant and $1.4 \%$ of intermediate tree cover. Mixed aspen and white spruce stands had slightly higher basal areas per plot $\left(343 \mathrm{~m}^{2} / \mathrm{ha}\right)$ compared to pure white spruce stands $\left(310 \mathrm{~m}^{2} / \mathrm{ha}\right)$. However, this difference was not significant when density of aspen exceeded 1000 per hectare. Average basal area also correlated with average age (Figure 4).

Table 1. Percentage of density of tree, seedling and sapling of the species to be included in the analysis.

\begin{tabular}{|c|c|c|c|c|c|c|}
\hline Species & $\begin{array}{c}\text { Number of tree } \\
\text { (400 square meter) }\end{array}$ & $\%$ & $\begin{array}{l}\text { Number of sapling } \\
\text { (25 square meter) }\end{array}$ & $\%$ & $\begin{array}{l}\text { Number of seedling } \\
\text { (1 square meter) }\end{array}$ & $\%$ \\
\hline White spruce & 2577 & $87.5 \%$ & 645 & $67.8 \%$ & 2426 & $65.8 \%$ \\
\hline Trembling aspen & 360 & $12.2 \%$ & 292 & $30.7 \%$ & 1173 & $31.4 \%$ \\
\hline Balsam poplar & 7 & $0.3 \%$ & 14 & $1.5 \%$ & 95 & $2.6 \%$ \\
\hline Total & 2944 & $100 \%$ & 951 & $100 \%$ & 3694 & $100 \%$ \\
\hline
\end{tabular}

[Note: The above table shows that white spruce has the highest density of tree, seedling and sapling. However, compared to tree density, the \% of its seedling and sapling are lower. In case of trembling aspen, tree stem coverage is $12.2 \%$ only but it has more than $30 \%$ seedling and sapling coverage.]

Table 2. Stand composition index.

\begin{tabular}{ccc}
\hline Species & Basal area $\left(\mathbf{m}^{2}\right)$ & Index \\
White spruce & 1253.4 & 0.907932 \\
Trembling aspen & 124.736 & 0.090356 \\
Balsam poplar & 2.344 & 0.001698 \\
Total & 1380.5
\end{tabular}

[Note: The above table shows the stand composition index for each species (Huang and Titus, 1995). White spruce has the highest composition followed by trembling aspen and balsam poplar.] 

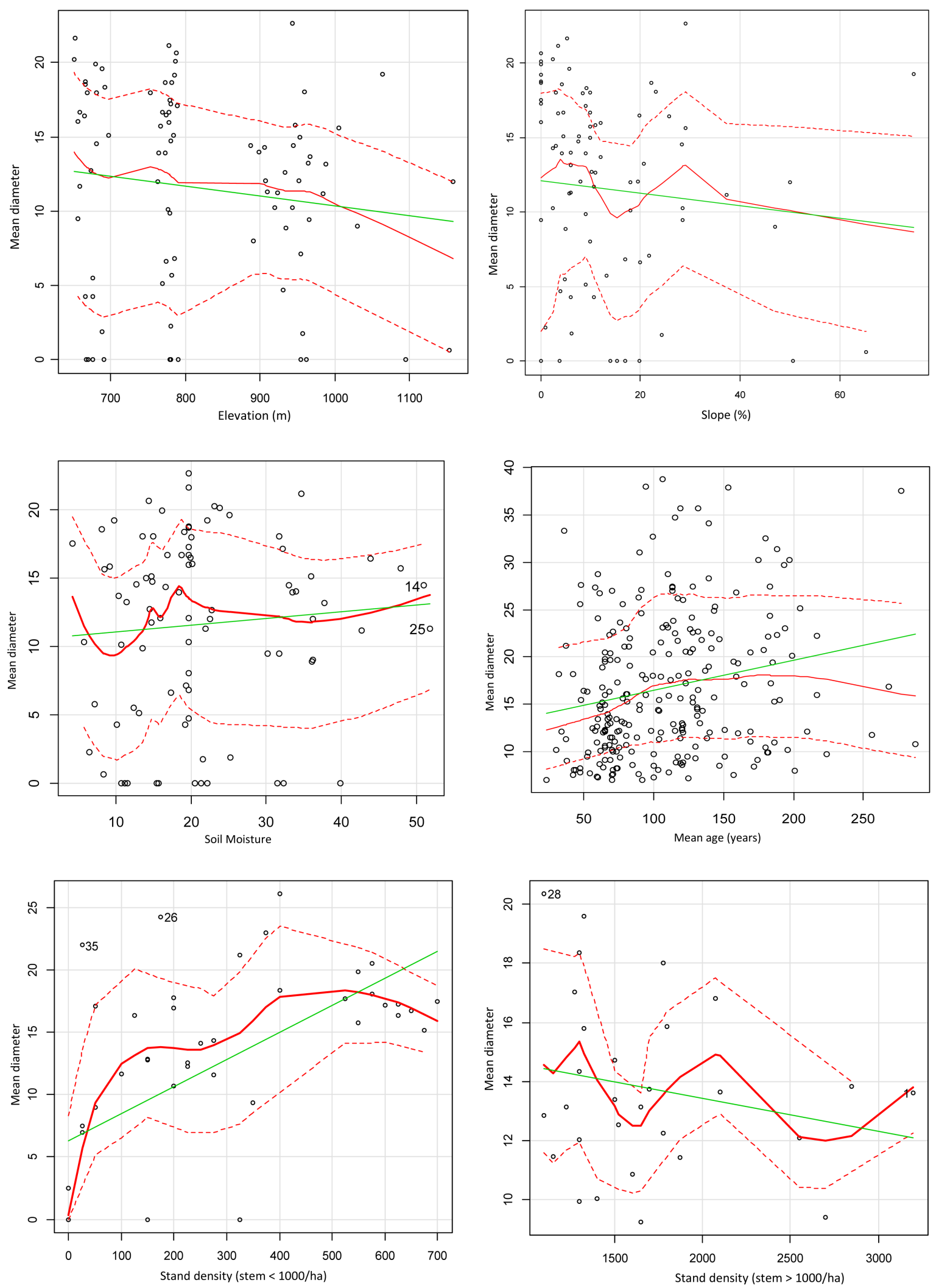

Figure 2. Variations of white spruce average diameters. Average diameter was lower at higher elevation, higher slope position and stand density higher than 1000 stems/ha. But average diameter was higher in moist area in old stands. 

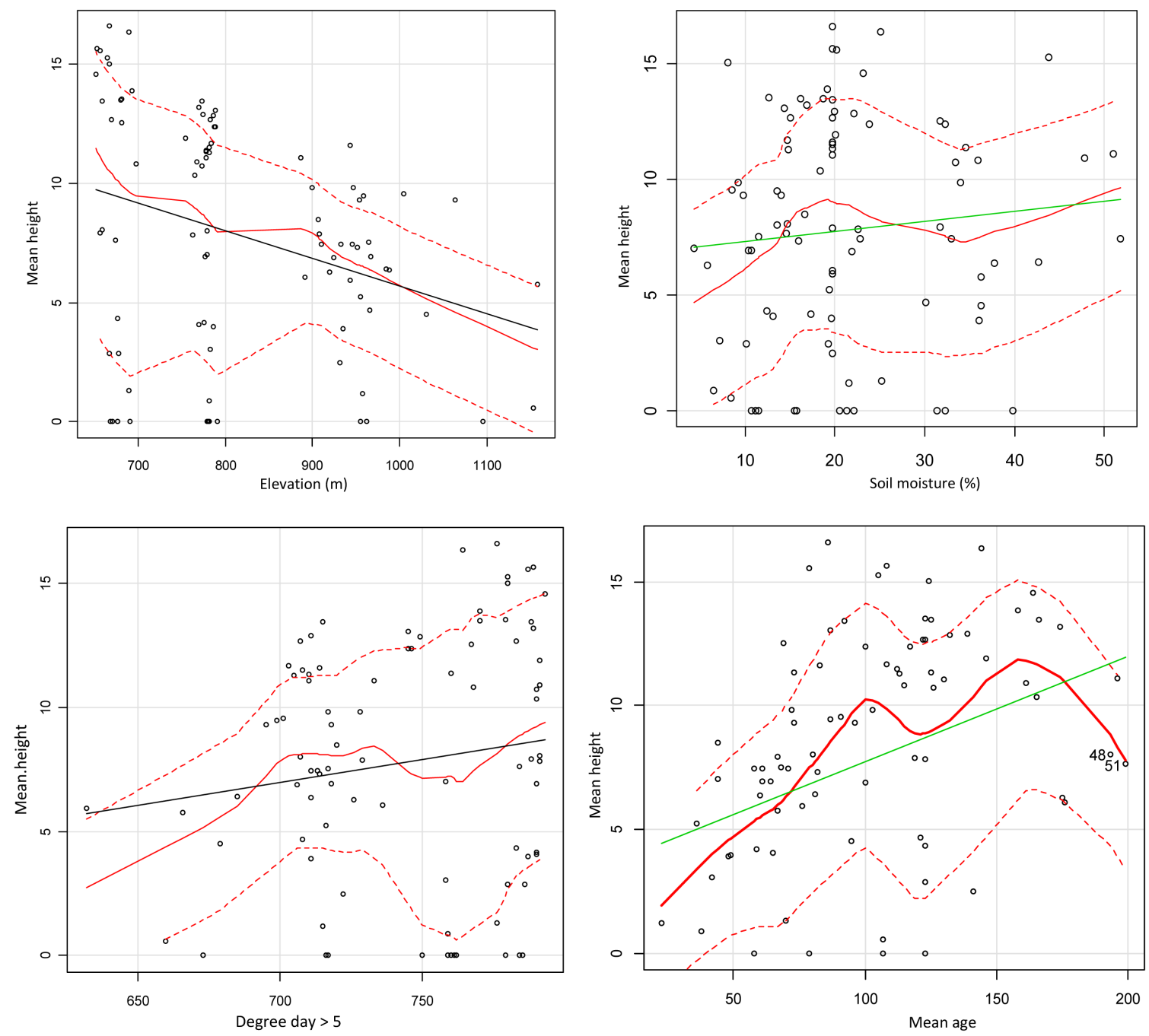

Figure 3. Variations of white spruce average heights. Average heights were higher in moist sites with higher growing days in old stands. However average height was significantly lower in higher elevation.

Table 3. Average height, diameter and basal area of the sampled tree species by dominant class.

\begin{tabular}{cccccccc}
\hline Species & $\begin{array}{c}\text { Dominant class } \\
\text { (height class) }\end{array}$ & $\begin{array}{c}\text { Total tree } \\
\text { sampled (no.) }\end{array}$ & $\begin{array}{c}\text { \% of total } \\
\text { sampled }\end{array}$ & $\begin{array}{c}\text { Average } \\
\text { height }(\mathbf{m})\end{array}$ & $\begin{array}{c}\text { Average } \\
\text { diameter }(\mathbf{c m})\end{array}$ & $\begin{array}{c}\text { Total basal } \\
\text { area } \mathbf{( m}^{2} \text { ) }\end{array}$ & $\begin{array}{c}\text { \% of total } \\
\text { Basal Area }\end{array}$ \\
\hline White & Dominant & 63 & 18.3 & 15.99 & 25.65 & 12.81 & 23.19 \\
spruce & Co-dominant & 71 & 20.6 & 12.54 & 19 & 23.55 & 42.64 \\
& Intermediate & 84 & 24.3 & 7.32 & 9.88 & 11.26 & 20.39 \\
& Suppressed & 45 & 13.0 & 6.6 & 8.4 & 2.53 & 4.58 \\
Trembling & Dominant & 19 & 5.5 & 11.36 & 18.95 & 1.15 & 2.08 \\
Aspen & Co-dominant & 26 & 7.5 & 8.58 & 14.08 & 3.15 & 5.70 \\
& Intermediate & 23 & 6.7 & 5.96 & 7.42 & 0.67 & 1.21 \\
& Suppressed & 7 & 2.0 & 3.29 & 4.31 & 0.022 & 0.04 \\
Balsam & Dominant & 2 & 0.6 & 7.35 & 15.1 & 0.07 & 0.13 \\
Poplar & Co-dominant & 0 & 0.0 & 0 & 0 & 0 & 0.00 \\
& Intermediate & 5 & 1.4 & 4.58 & 6.68 & 0.022 & 0.04 \\
\hline
\end{tabular}

[Note: The above table shows that white spruce intermediate height class has the highest density (24.3\%) but its co-dominant height class has significantly highest basal area (42.64\%).] 

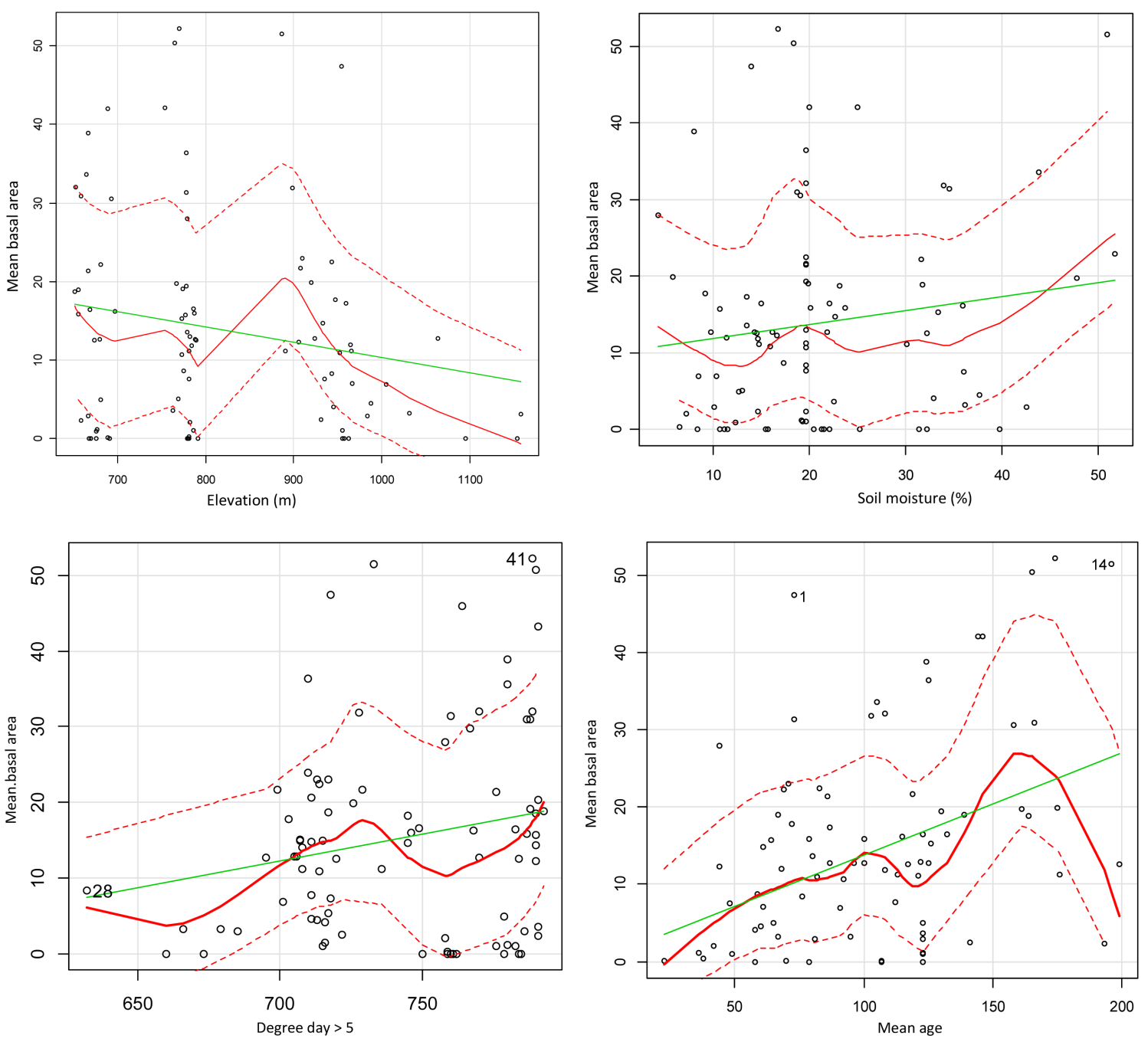

Figure 4. Variations of average stand basal area. As with diameter, basal areas were higher in moist old stands with higher grow degree days. Basal area was higher at lower altitude.

\subsubsection{Variation in Stand Structure Variables by Climatic, Topographic and Edaphic Factors}

Variation in stand diameter: Average diameters of white spruce and trembling aspen varied significantly with certain environmental factors (Figure 2, Table 4). Diameter of white spruce increased with decreasing slope percentage and elevation. Diameter did not vary with any of the climatic factors. Diameter was positively correlated with height $\left(r^{2}=0.89 ; P<.05\right)$, basal area $\left(r^{2}=0.43 ; P<.05\right)$ and tree density $\left(r^{2}=0.23 ; P<.05\right.$. However, the diameter decreased when the average stand density exceeded 1000 trees per hectare (Figure 2).

Diameter of trembling aspen was higher in plots with loamy sand soil and at lower elevation. Trembling aspen average diameter was positively but weakly correlated with stand density $\left(r^{2}=0.20 ; P<.05\right)$ and basal area $\left(r^{2}=0.30 ; P<.05\right)$. The relationships between the average diameter of balsam poplar and environmental variables were not significant.

Variation in stand height: White spruce average heights were shorter in higher elevations. Average heights were higher in sites with higher soil moisture and higher number of growing degree days (Figure 3). Similarly, average height of trembling aspen significantly higher at lower elevation and on sites with loamy sand soils (Table 4). Like with diameter, the average height of balsam poplar was not significantly related to any environmental variables.

Variation in stand basal area: Average stand basal area decreased with increasing elevation and slope (Table 4, Figure 4). It also increased with increasing soil moisture and number of growing degree days $>5^{\circ} \mathrm{C}$ (Figure 4). Basal area was also significantly co-related with average stand age (Figure 4). White spruce basal area was 
Table 4. Relationship between structural variables and environment factors of white spruce and trembling aspen.

\begin{tabular}{|c|c|c|}
\hline & White spruce & Trembling aspen \\
\hline Height (Ht) & $\begin{array}{c}\text { Elevation }\left(\mathrm{F}=7.39 ; P<.001 ; \mathrm{R}^{2}=0.19\right) \\
\mathrm{Ht}=17.3-.011^{*} \text { Elevation } \\
\text { Slope }\left(\mathrm{F}=4.62 ; P=.037 ; \mathrm{R}^{2}=0.12\right) \\
\mathrm{Ht}=8.5-0.056^{*} \text { slope } \\
\text { Age }\left(\mathrm{F}=26.05 ; P<.0001 ; \mathrm{R}^{2}=0.21\right) \\
\mathrm{Ht}=3.44+0.043^{*} \text { age }\end{array}$ & $\begin{array}{c}\text { Elevation }(\mathrm{F}=2.64 ; P=.02) \\
\mathrm{Ht}=829.34-3.74 * \text { Elevation } \\
\text { Mean annual precipitation }(\mathrm{F}=65 ; P<.01) \\
\text { Aspect }^{*}(\mathrm{~F}=3.75 ; P<.05) \\
\text { Soil texture }^{*}(\mathrm{~F}=2.71 ; P<.001)\end{array}$ \\
\hline Diameter (Dia) & $\begin{array}{c}\text { Elevation }\left(\mathrm{F}=3.67 ; P=0.046 ; \mathrm{R}^{2}=0.13\right) \\
\text { Dia }=1.27-0.0081^{*} \text { elevation } \\
\text { Stand density }\left(\mathrm{F}=26.6 ; P<.001 ; \mathrm{R}^{2}=0.29\right) \\
\text { Dia }=8.36+.004^{*} \text { stand density } \\
\text { Age }\left(\mathrm{F}=11.4 ; P<.001 ; \mathrm{R}^{2}=0.18\right) \\
\text { Dia }=7.3+0.41^{*} \text { age }\end{array}$ & $\begin{array}{c}\text { Soil texture }\left(\mathrm{F}=2.41 ; P<.001 ; \mathrm{R}^{2}=0.26\right) \\
\text { Diameter }=0.965+0.03^{*} \mathrm{SA} \\
\text { Mean annual precipitation (MAP) } \\
\left(\mathrm{F}=5.7 ; P<.01 ; \mathrm{R}^{2}=0.22\right) \\
\text { Diameter }=16.68-0.64^{*} \text { MAP }\end{array}$ \\
\hline Basal area (BA) & $\begin{array}{c}\text { Elevation }\left(\mathrm{F}=3.13 ; P<.05 ; \mathrm{R}^{2}=0.17\right) \\
\mathrm{BA}=1.28-.0081^{*} \text { elevation } \\
\text { Slope }\left(\mathrm{F}=5.38 ; P=.03 ; \mathrm{R}^{2}=0.14\right) \\
\mathrm{BA}=-0.707+.0076^{*} \text { slope } \\
\text { Number of days }>5^{\circ} \mathrm{C}\left(\mathrm{F}=3.35 ; P=.042 ; \mathrm{R}^{2}=0.23\right) \\
\mathrm{BA}=-0.47+0.0028^{*} \mathrm{DD} 5 \\
\text { Age }\left(\mathrm{F}=5.8 P=<.05 ; \mathrm{R}^{2}=0.31\right) \\
\mathrm{BA}=3.88+0.113^{*} \text { age } \\
\text { Disturbance type }(\mathrm{F}=10.48 ; P<.001)\end{array}$ & $\begin{array}{c}\text { Aspect }^{*}(\mathrm{~F}=4.21 ; P<.05) \\
\text { Soil texture }^{*}(\mathrm{~F}=3.83 ; P<.05)\end{array}$ \\
\hline
\end{tabular}

[Note: The above table showed the relationship of structural variables of white spruce and trembling with climatic, topographical, edaphic and disturbance variables. The categorical independent variables ${ }^{*}$ were tested by using ANOVA (with means of plots) and numerical variables were tested by using linear regression. The only variables which were significant at $P<.05$ are listed above. Structural variables of balsam poplar were not significant and therefore are not included here].

correlated with tree density, average height and diameter, with $\mathrm{r}^{2}$ values of $0.73,0.48$ and $0.43(P<.05)$, respectively. Basal area of aspen was higher on NE and SW aspects and on sandy to loamy sand soils. Aspen basal area was weakly correlated with its diameter $\left(\mathrm{r}^{2}=0.3 ; P<.05\right)$ and height $\left(\mathrm{r}^{2}=0.25 ; P<.05\right)$; but was strongly related to its density $\left(r^{2}=0.76 ; P<.05\right)$.

\subsubsection{Relationship between Forest Disturbance and Stand Structure}

The density index results (Table 5) showed that the density of white spruce was higher than average (100\%) in beetle-affected plots (196\%) and old fire plots (120\%) and much lower in the recent fire plots (32\%). However, the number of white spruce seedlings was higher in fire plots (205\%), followed by beetle plots (157\%). Similarly, the density of aspen trees was higher than average in the old fire (197\%) and undisturbed plots (137\%) and less than average in recent fire plots (20\%). Aspen saplings and seedlings had higher than average densities in the harvesting and fire plots. The density of balsam poplar trees, saplings and seedlings was higher than average in harvesting plots (257\% and 418\% respectively), and its seedlings had higher than average densities in the fire plots (370\%).

The ratios of tree regeneration to mature trees are shown in Table 6. With the exception of the fire and harvesting plots, the ratios were less than 1, indicating fewer seedlings and saplings than parent trees. However, with aspen, the ratio was higher than 1 in all the disturbance regimes, indicating greater numbers of regenerating trees than mature trees. The ratio was very high in fire plots (1:60 for white spruce and 1:45 for aspen). Although, the number of balsam poplar trees was negligible in the plots, regeneration (consisting of a few individuals) was found in both the fire and harvested sites.

\subsubsection{Species Environmental Relationship Using Multiple Co-Inertia Analysis (MCA)}

MCA provides a clear indication of the relationship between stand structure and environmental variables (Figure 5). The average height of white spruce increases with increasing summer maximum mean temperature, eastern aspect (Sin aspect), degree days below $0^{\circ} \mathrm{C}$ and decreases with increasing slope and elevation. Similarly, trembling aspen average diameter increases with increasing degree days more than $5^{\circ} \mathrm{C}$ but decreases with increasing depth of organic soil, elevation and slope. Balsam poplar diameter and height increase with increasing mean annual temperature, number of frost free days and minimum average summer temperature. The species/ environment axis (Figure 6) shows a similar trend. White spruce diameter increased with mean annual precipitation and trembling aspen height decreased with increasing elevation and slope. 


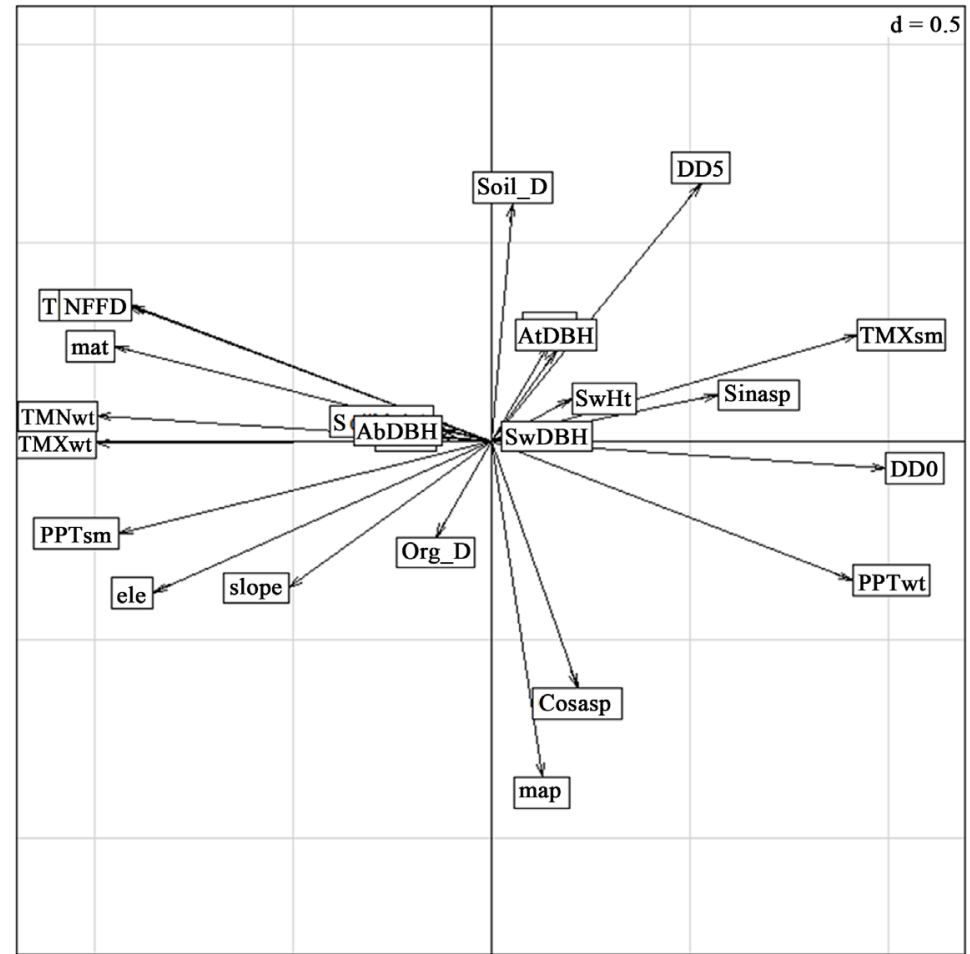

Figure 5. MCoA Axis I-Environmental/structure variables. [Note: Figure 5 shows that the average height of white spruce increases with increasing summer maximum mean temperature, eastern aspect and decreases with increasing slope, elevation and summer precipitation. Similarly, trembling aspen average diameter increases with increasing degree days more than $5^{\circ} \mathrm{C}$ but decreases with elevation and slope. Note: Abbreviation of names: NFFD = number of frost free days; mat = mean annual temperature; $\mathrm{TMNwt}=$ minimum winter temperature; $\mathrm{TMXwt}=$ maximum winter temperature; $\mathrm{AbDBH}=$ average DBH of balsam poplar; PPTsm = average precipitation; ele = elevation; Org_D = organic depth; Soil_D = soil depth; DD5 = number of days above $5^{\circ} \mathrm{C}$; AtDBH $=$ Average $\mathrm{DBH}$ of aspen; $\mathrm{TMXsm}=$ Maximum summer temperature; map = mean annual precipitation; $\mathrm{SwHt}=$ white spruce average height; SwDBH = white spruce average diameter; Sinasp = Sin of aspect; Cosasp $=$ Cos of aspect; $\mathrm{DDO}=$ number of days below $0^{\circ} \mathrm{C}$; PPTwt $=$ Winter precipitation].

Table 5. Comparing density index by disturbance types.

\begin{tabular}{ccccccc}
\hline Species & $\begin{array}{c}\text { Index for } \\
\mathbf{9 0} \text { plots (\%) }\end{array}$ & $\begin{array}{c}\text { Beetle } \\
\text { Plots (\%) }\end{array}$ & $\begin{array}{c}\text { Fire plots } \\
\text { (\%) }\end{array}$ & $\begin{array}{c}\text { Harvesting } \\
\text { plots (\%) }\end{array}$ & $\begin{array}{c}\text { Old fire } \\
\text { plots (\%) }\end{array}$ & $\begin{array}{c}\text { Undisturbed } \\
\text { plots (\%) }\end{array}$ \\
\hline White spruce tree & 100 & 192 & 32 & 71 & 120 & 92 \\
White spruce sapling & 100 & 141 & 70 & 74 & 157 & 83 \\
White spruce seedling & 100 & 157 & 205 & 73 & 67 & 70 \\
Trembling aspen tree & 100 & 30 & 20 & 80 & 179 & 137 \\
Trembling aspen sapling & 100 & 2 & 104 & 177 & 59 & 111 \\
Trembling aspen seedling & 100 & 18 & 322 & 94 & 96 & 64 \\
Balsam poplar tree & 100 & 0 & 0 & 257 & 92 & 83 \\
Balsam poplar sapling & 100 & 0 & 58 & 418 & 0 & 0 \\
Balsam poplar seedling & 100 & 7 & 370 & 204 & 0 & 24
\end{tabular}

[Note; The above table shows \% of tree, sapling and seedling in each disturbance type compared to mean value of 90 plots. It indicates that white spruce tree was higher in beetle affected and old fire plots. Both trembling aspen and balsam poplar regeneration were higher in fire and harvesting plots.] 


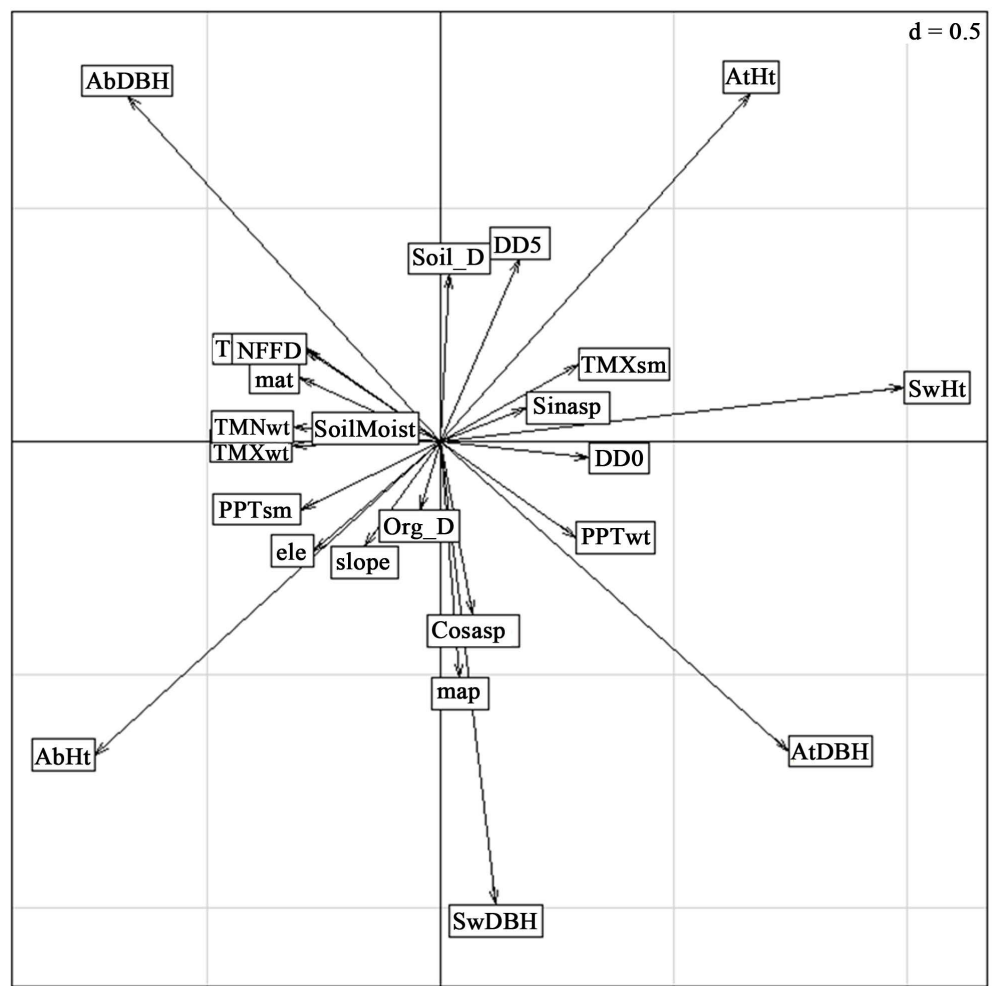

Figure 6. MCoA Axis II-Species environmental axis. (Note: Figure 6 provides additional information. It indicates that white spruce average diameter increases with increasing mean annual precipitation and trembling aspen average height decreases with increasing elevation and slope. Abbreviation of names: same as in Figure 5).

Table 6. Ratio of tree regeneration with their parent trees along the disturbance regime (values are averaged per plot).

\begin{tabular}{cccccccccc} 
& STT & Spsed & STT:Spsed & ATT & Atsed & ATT: Atsed & PTT & Posed & PTT: Posed \\
\hline Beetle (16 plots) & 55 & 52 & $1: 0.95$ & 1 & 2 & $1: 2$ & 0 & 0 & 0 \\
Fire (10 plots) & 9 & 59 & $1: 6.6$ & 1 & 45 & $1: 45$ & 0 & 4 & $0: 4$ \\
Harvesting (20 plots) & 20 & 25 & $1: 1.25$ & 3 & 18 & $1: 6$ & 2 & 3 & $1: 1.5$ \\
Old fire (16 plots) & 34 & 29 & $1: 0.85$ & 7 & 15 & $1: 2.14$ & 0 & 0 & 0 \\
Undisturbed (28 plots) & 26 & 25 & $1: .96$ & 5 & 12 & $1: 2.4$ & 0 & 0 & 0 \\
\hline
\end{tabular}

[Note: The table shows that trembling aspen has much higher ratio of tree to regeneration in disturbed plots than that of white spruce. Abbreviation of names: STT = white spruce tree density; Spsed = white spruce seedling density; ATT = apsen tree density; Atsed = aspen seedling density; PTT = balsam poplar tree density; Poseed = balsam poplar seedling density.]

\section{Discussion}

\subsection{Relationship among Stand Density, Basal Area, Age and Tree Size}

Tree size vs stand density: We found an inverse relationship between tree size and stand density for spruce, in agreement with our first hypothesis that diameter declines with increasing density. The density of co-dominant white spruce was $4 \%$ less than that of the intermediate class, but the basal area was $22 \%$ higher (Table 3 ), indicating that there is an inverse relationship between tree size and density of the stand and that the average diameter plays a greater role than density in increased forest productivity (basal area). The results also indicated that a decreasing trend in the average diameter of white spruce occurs when tree density exceeds 1000 stems per hectare (SPH). Generally, stand density has an inverse relationship with tree size (Lee et al., 1997; Delong and Kessler, 
2000; Martin and Gower, 2006), resulting in old growth stands having larger trees and lower densities due to self-thinning processes (Delong and Kessler, 2000). Our results suggest that this relationship holds true below 1000 SPH; at greater stand densities tree size may become limited by inter-specific competition, whereas at lower densities other factors are at play (Huang and Titus, 1995). The results suggest that thinning and selective harvesting in dense stands could play an important role in increasing forest productivity in the region.

White spruce age vs. size: The ages of white spruce were correlated with height, diameter, and basal area. However, McCarthy and Weetman (2006) reported from their study in Newfoundland that the age difference of trees with equal height and diameter could be more than 120 years. In our study, trees of similar size were found to be $>120$ years apart, indicating that tree size is a poor indicator for defining old growth stands.

Stand type vs. species basal area and density: Our finding of higher basal area in mixed stands than in pure white spruce stands contrasts with our expectation that productivity would be higher in pure than mixed stands. Linder (1998) also reported similar findings in his study in central Sweden, namely that the basal area was more than $21 \%$ higher in mixed stands compared to pure coniferous stands. In this regard, Kabzem et al. (2007) suggest that the presence of a small amount of aspen has a large effect on spruce productivity but that this effect diminishes when the aspen density is greater than 1000 stems per hectare. However, Stewart et al. (2003) reported that the basal area of pure coniferous stands was higher compared to mixed wood stands. Similarly, Hély et al. (2000) reported higher basal areas in deciduous forests followed by coniferous and mixed stands, but Linder (1998) and Stewart et al. (2003) found lower BA in deciduous stands than old mixed woods or coniferous stands. The reason for the higher basal areas of mixed wood stands in this study may be due to the presence of higher stand densities in mixed stands compared to pure stands in the study area.

\subsection{Variation of Stand Structures by Edaphic and Topographic Factors}

Stand height and diameter: In this study average heights and diameters of both trembling aspen and white spruce were higher at sites at lower elevation, and on lower slope positions, agreeing with the expectations in our first hypothesis. Site productivity has been suggested as one of the main factors influencing the diameter structure of coniferous stands (Boucher et al., 2006). As soil properties can affect the height growth of boreal trees (Martin and Gower, 2006), lower rates of decomposition and high rates of leaching can cause lower nutrient availability at higher elevations and on steep slopes (Vitousek et al., 1988; Cole, 1995), and these factors may have affected the lower height and diameter growth in higher elevations in this study.

White spruce's growth responded positively to soil moisture. Soil moisture has been reported to be one of the important factors affecting site index of white spruce (Wang, 1995); it also controls the southern limit of white spruce in western Canada (Chhin and Wang, 2008). Similarly, higher average spruce diameters and heights were found on NE and south aspects and the lowest on N or SE aspects. The reduced diameter growth on the $\mathrm{N}$ aspect can be explained by lower temperature, reduced availability of light and thereby shorter growing seasons. Conversely, the reduced diameter on SE aspects could be due to temperature-induced drought (Barber et al., 2000; Juday et al., 2003). Generally hot, dry, summer conditions are exacerbated on S and SE aspects, and may reduce radial growth (Chapin et al., 2004; Barber et al., 2004). Temperature-induced summer droughts in the western boreal region were recorded by Barber et al. (2000).

Stand basal area: We found that forest productivity (basal area per hectare) varied significantly by geographical position, with higher basal area at lower elevations. This could have important implications for prescribing site-specific silvicultural systems in the study area. A similar trend was found in interior and northern British Columbia (Klinka et al., 1996), and north-western Quebec (Chen et al., 1998 and Boucher et al., 2006). White spruce basal area was higher in older stands consistence with the findings of Popadiouk et al. (2003), who reported increasing basal area with stand age in eastern boreal mixed woods.

\subsection{Variation of Stand Structure with Disturbance Regime}

In this study, disturbances had significant effects on forest composition including species densities and their regeneration confirming our second hypothesis. Disturbances had promoted the development of a broadleaved forest in the region. A higher density of white spruce regeneration was found in plots with some kind of past disturbance such as fire or spruce bark beetle, meeting our expectation that white spruce regeneration density would increase with disturbance. The higher regeneration of trembling aspen in recently harvested fire plots in- 
dicated that fire promotes aspen regeneration and that the gap dynamics created by these disturbances (harvested plots had 29\% mean crown coverage) were sufficient to promote the regeneration of this light-demanding species (Cumming et al., 2000; Kuusela, 1990). Similarly, balsam poplar and its regeneration were also higher in disturbed forests, particularly in harvested plots. Balsam poplar, like trembling aspen, is a shade-intolerant species and prefers open areas to regenerate and grow (Alexander et al., 1990). Although disturbances favour regeneration of all three species, the increased proportion of broadleaves following disturbance met our expectation that the proportion of broadleaved trees and regeneration would increase with disturbance.

\subsection{Variation of Stand Structures with Climatic Factors}

We partially accept the third research hypothesis, that one or more climatic variables (e.g. MAT, MAP, TMXsm and NFFD) significantly affect the stand structure of all three species. We found higher basal area of white spruce on sites with a higher accumulation of growing degree-days and higher soil moisture. Similarly, the results of the multivariate analysis suggested that average diameter increases with increasing mean annual precipitation. These two results are consistent with our expectation that stand productivity would be greater on warmer and wetter locations. This expands the understanding of Wang and Klinka (1996) in their study in British Columbia, who suggested that the site productivity of white spruce was mostly influenced by edaphic factors rather than by climate. In contrast, Chavardes et al. (2012), who undertook their study in the same research plots as our study, found that precipitation was important in determining the growth of white spruce, although the relationship varied month to month, with a negative relation found with April precipitation. Barber et al. (2000) reported that the radial growth of white spruce has decreased with increasing temperature in their study sites in Alaska, although this could be connected to soil moisture. Chavardes et al. (2012) also indicated that although white spruce growth was negatively related to maximum temperatures in general, increased precipitation accompanied by warmer temperature were correlated with increased tree growth in the last 30 years. It seems feasible that precipitation is a key factor affecting tree growth in the area but that it may interact negatively with increasing temperature. The mean annual precipitation in the study area is $319.5 \mathrm{~mm}$ (Wang et al., 2006), which is projected to increase by $20 \%$ (ACIA, 2004), which may favour spruce growth if temperature is not a limiting factor.The multivariate analysis used in this study suggested that the average height of white spruce increased with increasing summer maximum mean temperature. Climatic factors are considered more important than edaphic factors for white spruce height growth as height variations have been found in different climatic regions with the same edaphic site index (Wang et al., 1994). However, it has also been reported that summer drought caused by increased temperature and hence evapo-transpiration may limit the growth of white spruce (Barber et al., 2000). A similar result was found by Wilmking et al. (2004) in their study in Alaska.

\section{Conclusions and Recommendations}

Stand structure and composition have important implications for making forest management decisions. In southwest Yukon forest, some attributes of stand structure were significantly varied by edaphic, topographic and climatic factors. Although white spruce dominates the landscape in terms of its density, basal area, average height and $\mathrm{DBH}$, its regeneration (seedling and sapling) was proportionately less than that of trembling aspen, especially in disturbed plots, suggesting broadleaved species may prevail if disturbance persists in the region. This research also found that mixed stands of aspen and white spruce had higher basal areas per hectare than pure stands of trembling aspen or white spruce and that average stand diameter was positively correlated with tree density up to 1000 trees per hectare, beyond which the average diameter decreased.

Based on the findings, we suggest promoting mixed stands of deciduous and coniferous species where appropriate (Biringer, 2003; Bergeron and Harvey, 1997). However, we also suggest maintaining stand density below $1000 \mathrm{stem} / \mathrm{ha}$ in mixed stands as the productivity declined beyond this threshold. As the co-dominant height class had the highest average basal area and the average diameter of white spruce decreased with increasing stand density, indicating the overall productivity of white spruce decreases with increasing stand density, we suggest carrying out selection harvesting of co-dominant trees and regular thinning of intermediate trees to promote the height and diameter growth of the remaining trees. Commercial harvesting should focus on lower elevation where average basal area of white spruce was higher. These areas are easily accessible and would generate higher production with lower operational costs. 


\section{References}

Alexander, R. R., Shearer R. C., \& Sheppard, W. D. (1990). Subalpine Fir. In R. M. Burns, \& B. M. Honkala (Eds.), Silvics of North America, Volume 1: Conifers. Agriculture Handbook 654 (p. 1383). Washington, D.C.: United States Department of Agriculture and Forest Service.

Arctic Climate Impact Assessment (ACIA) (2004). Impacts of a Warming Arctic: Arctic Climate Impact Assessment. Cambridge: Cambridge University Press.

Barber, V. A., Juday, G. P., \& Finney, B. P. (2000). Reduced Growth of Alaskan White Spruce in the Twentieth Century from Temperature Induced Drought Stress. Nature, 405, 668-673. http://dx.doi.org/10.1038/35015049

Barber, V. A., Juday, G. P., Finney, B. P., \& Wilmking, M. (2004). Reconstruction of Summer Temperatures in Interior Alaska: Evidence for Changing Synoptic Climate Regimes. Climate Change, 63, 91-120. http://dx.doi.org/10.1023/B:CLIM.0000018501.98266.55

Berg, E. E., Henry, J..D., Christopher, L., Fastie, C. L., Volder, A. D., \& Matsuoka, S. M. (2006). National Park and Reserve, Yukon Territory: Relationship to Summer Temperatures and Regional Differences in Disturbance Regimes. Forest Ecology and Management, 227, 219-232. http://dx.doi.org/10.1016/j.foreco.2006.02.038

Bergeron, Y. \& Harvey, B. (1997). Basing Silviculture on Natural Ecosystem Dynamics: An Approach Applied to the Southern Boreal Mixed-Wood Forest of Quebec. Forest Ecology and Management, 92, 235-242. http://dx.doi.org/10.1016/S0378-1127(96)03924-2

Bergeron, Y. (1991). The Influence of Island and Mainland Lakeshore Landscapes on Boreal Forest Fire Regimes. Ecology, 72, 1980-1992. http://dx.doi.org/10.2307/1941553

Bergeron, Y. (2000). Species and Stand Dynamics in the Mixed Woods of Quebec's Southern Boreal Forest. Ecology, 81, 1500-1516. http://dx.doi.org/10.1890/0012-9658(2000)081[1500:SASDIT]2.0.CO;2

Bergeron, Y., \& Dubuc, M. (1989). Succession in Southern Part of the Canadian Boreal Forest. Vegetatio, 79, 51-63. http://dx.doi.org/10.1007/BF00044848

Bergeron, Y., \& Flannigan, M. D. (1995). Predicting the Effects of Climate Change on Fire Frequency in the Southeastern Canadian Boreal Forest. Water Air Soil Pollution, 82, 437-444. http://dx.doi.org/10.1007/BF01182853

Biringer, J. (2003). Forest Ecosystem Threatened by Climate Change: Promoting Long Term Forest Resilience. In L. J. Hansen, J. Biringer, \& J. R. Hoffman (Eds.), Buying Time: A User's Manual for Building Resistance and Resilience to Climate Change in Natural Systems (pp. 41-69). Gland: World Wide Fund for Nature.

Bonan, G. B., \& Shugart, H. H. (1989). Environmental-Factors and Ecological Processes in Boreal Forests. Annual Review of Ecology, Evolution and Systematics, 20, 1-28. http://dx.doi.org/10.1146/annurev.es.20.110189.000245

Boucher, D., Gauthier, S., \& De Grandpré, L. (2006). Structural Changes in Coniferous Stands along a Chronosequence and a Productivity Gradient in the North-Eastern Boreal Forest of Québec. Ecoscience, 13, 172-180.

Brassard, B. W., \& Chen, H. Y. H. (2006). Stand Structural Dynamics of North American Boreal Forests. Critical Review in Plant Sciences, 25, 115-137. http://dx.doi.org/10.1080/07352680500348857

Chapin III, F. S., Callaghan, T. V., Bergeron, Y., Fukuda, M., Johnstone, J. F., Juday, G., \& Zimov, S. A. (2004). Global Change and the Boreal Forest: Thresholds, Shifting States or Gradual Change? AMBIO, 33, 361-365.

Chavardes, R. D., Daniels, L. D., Waeber, P. O., Innes, J. L., \& Nitschke, C. R. (2012). Unstable Climate Growth Relations for White Spruce in Southwest Yukon, Canada. Climate Change, Online Publication.

Chen, H. Y. H., Klinka, K., \& Kabzems, R. D. (1998). Site Index, Site Quality, and Foliar Nutrients of Trembling Aspen: Relationships and Predictions. Canadian Journal of Forest Research, 28, 1743-1755. http://dx.doi.org/10.1139/x98-154

Chhin, S., \& Wang, G. G. (2008). Climatic Response of Picea glauca Seedlings in a Forest-Prairie Ecotone of Western Canada. Annals of Forest Science, 65, 207-214. http://dx.doi.org/10.1051/forest:2007090

Cole, W. D. (1995). Soil Nutrient Supply in Natural and Managed Forests. Plant and Soil, 168-169, 43-53. http://dx.doi.org/10.1007/BF00029312

Cumming, S. G., Schmiegelow, F. K. A., \& Burton, P. J. (2000). Gap Dynamics in Boreal Aspen Stands: Is the Forest Older Than We Think? Ecological Application, 10, 744-759.

Delong, S. C., \& Kessler, W. B. (2000). Ecological Characteristics of Mature Forest Remnants Left by Wildfire. Forest Ecology and Management, 131, 93-106. http://dx.doi.org/10.1016/S0378-1127(99)00203-0

Dray, S., Chessel, D., \& Thioulouse, J. (2003). Co-Inertia Analysis and the Linking of Ecological Data Tables. Ecology, 84, 3087-3089. http://dx.doi.org/10.1890/03-0178

Environmental Systems Resource Institute, ESRI (2009). ArcGIS 9.2. Redlands, CA: ESRI.

Flannigan, M. D., Bergeron, Y., Engelmark, O., \& Wotton, B. M. (1998). Future Wildfire in Circum Boreal Forests in Relation to Global Warming. Journal of Vegetation Science, 9, 469-476. http://dx.doi.org/10.2307/3237261 
Frugal, C., \& Prowse, T. D. (2008). Northern Canada. In D. S. Lemmen, F. J. Warren, J. Lacroix, \& E. Bush (Eds.), From Impacts to Adaptation: Canada in a Changing Climate (pp. 57-118). Ottawa, ON: Government of Canada.

Government of Yukon (2004). Strategic Forest Management Plan for Champagne and Aishihik Territory. Government of Yukon and Champagne and Aishihik First Nation Government. http://www.emr.gov.yk.ca/forestry/pdf/CATTPlan___Final.pdf

Government of Yukon (2010). Yukon Forest Health Report. http://www.emr.gov.yk.ca/forestry/pdf/forest_health_report_2010.pdf

Hély, C., Bergeron, Y., \& Flannigan, M. D. (2000). Effects of Stand Composition on Fire Hazard in Mixed-Wood Canadian Boreal Forest. Journal of Vegetation Science, 11, 813-824. http://dx.doi.org/10.2307/3236551

Huang, S., \& Titus, S. J. (1995). An Individual Tree Diameter Increment Model for White Spruce in Alberta. Canadian Journal of Forest Research, 25, 1455-1465. http://dx.doi.org/10.1139/x95-158

Johnson, E. A., Morin, H., Miyanishi, K., Gagnon, R., \& Greene, D. F. (2003). A Process Approach to Understanding Disturbance and Forest Dynamics. In: P. J. Burton, C. Messier, D. W. Smith, \& W. L. Adamowicz (Eds.), Towards Sustainable Management of the Boreal Forest (p. 1039) Ottawa, Ontario: National Research Council of Canada Research Press.

Johnstone, J. F., Chapin, F. S., Foote, J., Kemmett, S., Price, K., \& Viereck, L. (2004). Decadal Observations of Tree Regeneration Following Fire in Boreal Forests. Canadian Journal of Forest Research, 34, 267-273. http://dx.doi.org/10.1139/x03-183

Juday, G. P., Barber, V., Rupp, S., Zasada, J., \& Wilmking, M. (2003). A 200-Year Perspective of Climate Variability and the Response of White Spruce in Interior Alaska. In D. Greenland, D. G. Goodin, \& R. C. Smith (Eds.), Climate Variability and Ecosystem Response at Long-Term Ecological Research Sites (pp. 226-250). New York: Oxford University Press.

Kabzem, R., Nemec, A. M., \& Farnden, C. (2007). Growing Trembling Aspen and White Spruce Intimate Mixtures: Early Results (13-17 years) and Future Projections. BC Journal of Ecosystems and Management, 8, 1-14.

Kimmins, J. P. (1997). Biodiversity and Its Relationship to Ecosystem Health and Integrity. Forest Chronicle, 73, $229-232$. http://dx.doi.org/10.5558/tfc73229-2

Kindt, R., \& Coe, R. (2005). Tree Diversity Analysis. A Manual and Software for Common Statistical Methods for Ecological and Biodiversity Studies. Nairobi: World Agroforestry Centre (ICRAF).

Klinka, K., Wang, Q., Carter, R. E., \& Chen, H. Y. H. (1996). Height Growth-Elevation Relationships in Subalpine Forests of Interior British Columbia. Forestry Chronicle, 72, 193-198. http://dx.doi.org/10.5558/tfc72193-2

Kuuluvainen, T. (2002). Natural Variability of Forests as a Reference for Restoring and Managing Biological Diversity in Boreal Fennoscandia. Silva Fennica, 36, 97-125. http://dx.doi.org/10.14214/sf.552

Kuusela, K. (1990). Dynamics of Boreal Coniferous Forests. SITRA 112, Helsinki.

Larsen, J. A. (1980). The Boreal Ecosystem. New York: Academic Press, 500 p.

Lee, O. C., Crites, S., Nietfeld, M., Nguyan, V. H., \& Stelfox, J. B. (1997). Characteristics and Origins of Deadwood Material in Aspen-Dominated Boreal Forests. Ecological Applications, 7, 691-701. http://dx.doi.org/10.1890/1051-0761(1997)007[0691:CAOODM]2.0.CO;2

Linder, P. (1998). Structural Changes in Two Virgin Boreal Forest Stands in Central Sweden over 72 Years. Scandinavian Journal of Forest Research, 13, 451-461. http://dx.doi.org/10.1080/02827589809383006

Lloyd, A. H., \& Fastie, C. L. (2002). Spatial and Temporal Variability in the Growth and Climate Response of Treeline Trees in Alaska. Climatic Change, 52, 481-509. http://dx.doi.org/10.1023/A:1014278819094

Lorimer, C. G. (1989). Relative Effects of Small and Large Disturbances on Temperate Hardwood Forest Structure. Ecology, 70, 565-567. http://dx.doi.org/10.2307/1940207

Martin, J. L., \& Gower, S. T. (2006). Boreal Mixedwood Tree Growth on Contrasting Soils and Disturbance Types. Canadian Journal of Forest Research, 36, 986-995. http://dx.doi.org/10.1139/x05-306

McCarthy, J. W., \& Weetman, G. (2006). Age and Size Structure of Gap-Dynamic, Old-Growth Borealforest Stands in Newfoundland. Silva Fennica, 40, 209-230. http://dx.doi.org/10.14214/sf.339

McCoy, V. M., \& Burn, C. R. (2005). Potential Alteration by Climate Change of the Forest-Fire Regime in the Boreal Forest of Central Yukon Territory. Arctic, 58, 276-285.

Northern Climate ExChange, NCE (2006). Forest Management in a Changing Climate: Building the Environmental Information Base for Southwest Yukon. Climate Change and Ecosystem Dynamics in the Southwest Yukon (Backgrounder). Northern Climate ExChange, Yukon Research Centre, Yukon College.

Payette, S., Morneau, C., Sirois, L., \& Desponts, M. (1989). Recent Fire History of the Northern Quebec Biomes. Ecology, 70, 656-673. http://dx.doi.org/10.2307/1940217 
Popadiouk, R. V., Chen, H. Y. H., Bowling, C., \& Vasiliauskas, S. A. (2003). Compositional and Structural Characteristics of Ontario's Boreal Mixedwoods. Ontario Ministry of Natural Resources, NESI TR-045. Toronto: Queen's Printer for Ontario.

R Development Core Team (2012). R: A Language and Environment for Statistical Computing. Vienna: R Foundation for Statistical Computing. http://www.R-project.org

Stewart, B. J., Neily, P. D., Quigley, E. J., Duke, A. P., \& Benjamin, L. K. (2003). Selected Nova Scotia Old-Growth Forests: Age, Ecology, Structure, Scoring. Forestry Chronicle, 79, 632-644. http://dx.doi.org/10.5558/tfc79632-3

Vitousek, P. M., Matson, P. A. and Turner, D. R. (1988). Elevational and Age Gradients in Hawaiian Montane Ain Forest: Foliar and Soil Nutrients. Oecologia, 77, 565-570. http://dx.doi.org/10.1007/BF00377275

Wang, G. G., \& Klinka, K. (1996). Use of Synoptic Variables in Predicting White Spruce Site Index. Forest Ecology and Management, 80, 95-105. http://dx.doi.org/10.1016/0378-1127(95)03630-X

Wang, C. G. (1995). White Spruce Site Index in Relation to Soils, Understory Vegetation and Foliar Nutrients. Canadian Journal of Forest Research, 25, 29-38. http://dx.doi.org/10.1139/x95-004

Wang, G. G., Marshal, P. L., \& Klinka, K. (1994). Height Growth Pattern of White Spruce in Relation to Site Quality? Forest Ecology and Management, 68, 134-144. http://dx.doi.org/10.1016/0378-1127(94)90041-8

Wang, T., Hamann, A., Spittlehouse, D., \& Aitken, S. N. (2006). Development of Scale-Free Climate Data for Western Canada for Use in Resource Management. International Journal of Climatology, 26, 383-397. http://dx.doi.org/10.1002/joc.1247

Wardle, D. A., Bonner, K. I., \& Nicholson, K. S. (1997). Biodiversity and Plant Litter: Experimental Evidence Which Does Not Support the View That Enhanced Species Richness Improves Ecosystem Function. Oikos, 79, 247-258. http://dx.doi.org/10.2307/3546010

Wilmking, M., Juday, G. P., Barber, V. A., \& Zald, H. S. (2004). Recent Climate Warming Forces Contrasting Growth Responses of White Spruce at Treeline in Alaska through Temperature Thresholds. Global Change Biology, 10, 724-1736. http://dx.doi.org/10.1111/j.1365-2486.2004.00826.x 